\title{
Comparison of blood profiles between healthy and Brucella affected cattle
}

\author{
Rita Nath ${ }^{1}$, Sutopa Das², Satya Sarma ${ }^{1}$ and Maitrayee Devi² \\ 1. Department of Veterinary Biochemistry, College of Veterinary Science, Khanapara, Guwahati, Assam, India; \\ 2. Department of Microbiology, College of Veterinary Science, Khanapara, Guwahati, Assam, India. \\ Corresponding author: Rita Nath, email: ritasankr@rediffmail.com, SD: d_sutopa@yahoo.com, \\ SS: sarmasatya49@yahoo.in, MD: maitrayeee@gmail.com \\ Received: 23-05-2014, Revised: 20-07-2014, Accepted: 27-07-2014, Published online: 07-09-2014
}

doi: 10.14202/vetworld.2014.668-670. How to cite this article: Nath R, Das S, Sarma S, Devi M (2014) Comparison of blood profiles between healthy and Brucella affected cattle, Veterinary World 7(9): 668-670.

\begin{abstract}
Aim: The present investigation was undertaken to evaluate the blood biochemical metabolites of crossbred cattle suffering from brucellosis, in Khetri region of Kamrup District of Assam, India.

Materials and Methods: Blood was collected by venipuncture from the jugular vein using 18 gauge hypodermic needle fitted to a Vacutainer-Leur adapter and evacuated tubes. Samples were screened for Brucella by rose Bengal plate test using plate test antigen. The study consisted of two groups. Group I consisted of healthy crossbred cows and Group II consisted of crossbred cows affected with brucellosis. Blood metabolites were estimated by spectrophotometric methods.

Results: Out of 14 serum samples, 8 samples were positive for Brucella and remaining 6 were found to be negative. It was observed that serum albumin and urea of the affected cattle showed a significant decrease $(\mathrm{p}<0.05)$, but serum globulin, cholesterol, triglyceride, aspartate transaminase, and alanine transaminase activities were significantly increased $(\mathrm{p}<0.05)$ in comparison to the healthy cattle. Glucose, protein, albumin: globulin ratio, blood urea nitrogen did not show much variation between the Brucellosis affected and healthy cattle.
\end{abstract}

Conclusion: Results obtained showed that brucellosis have a harmful effect on the animals health as they disturb the vital organs functions, which appear in the form of changes in blood biochemical parameters.

Keywords: biochemical metabolites, brucellosis, cattle, rose Bengal plate test.

\section{I ntroduction}

Bovine brucellosis is usually caused by Brucella abortus, less frequently by Brucella melitensis, and occasionally by Brucella suis [1]. Brucellosis is a febrile zoonotic infection and has worldwide distribution among humans as well as animals [2,3]. Brucella is usually transmitted to humans through the consumption of raw milk and its products (milk cream, butter, and fresh cheese) or through contact with afterbirth products from infected animals [4,5]. Brucellosis may cause considerable economic losses especially it reduces productivity and leads to abortion that could result in temporary or permanent infertility in affected animals. The disease is usually asymptomatic in non-pregnant cows. The disease in cows is characterized by abortion and retained placenta and in male animals by orchitis and epididymitis [6].

The study of blood constituents can provide valuable information about the general health of the animal and, therefore, can be used for evaluating the health status of the animal. Brucellosis has serious effects on animal health because it infect vital organs in the body leading to their damage, impairment of their function and increase or decrease the release of their enzymes according to the stage of infection [7-9]. For the control of brucellosis at the national or local level, the buffered

Copyright: The authors. This article is an open access article licensed under the terms of the Creative Commons Attributin License (http:// creative commons.org/licenses/by/2.0) which permits unrestricted use, distribution and reproduction in any medium, provided the work is properly cited.
Brucella antigen tests, i.e. the rose Bengal test (RBT) and the buffered plate agglutination test, as well as the enzyme linked immunosorbent and the fluorescence polarization assay, are suitable screening tests. The RBT is very sensitive test. Although there are serious economic losses caused by brucellosis in ruminants, a very little information regarding the status of blood profile in cows suffering from brucellosis is available.

Keeping this in mind, this study was conducted with the objective to investigate the changes in biochemical metabolites of the cows diagnosed with brucellosis that reflect the effects of the disease on animals' health and performances.

\section{Materials and Methods}

\section{Ethical approval}

The prior approval from the Institutional Animal Ethical Committee was obtained for blood collection of the animals in this study.

\section{Experimental design}

In the present investigation, blood was collected from six healthy crossbred cows (Group I) and another 14 crossbred cows having history of abortion and infertility (Group II). All the animals were reared under free grazing condition in Khetri region of Kamrup district of Assam, India. Blood samples were collected early morning before feeding taking all aseptic precautions by venipuncture of the jugular vein using 18 gauge hypodermic needle fitted to a Vacutainer-Leur adapter and evacuated tube. 
Approximately, $10 \mathrm{ml}$ of blood was collected in Vacutainer tube containing ethylenediaminetetraacetic acid as the anti-coagulant. Plasma was separated from the blood by centrifugation at $3000 \mathrm{rpm}$ for $20 \mathrm{~min}$. Each sample was labeled using codes describing the specific animal. The blood samples taken from cows of group II having history of abortion and infertility were screened for Brucella using rose bengal plate test (RBPT) using plate test antigen (Biological Products Division, IVRI, Izatnagar) obtained from Department of Microbiology, College of Veterinary Science, Khanapara, Guwahati. The RBPT antigen is a suspension of pure, smooth killed cells of Brucella abortus strain 99 phenolized and stained with Rose Bengal dye. However, they can't differentiate between strains. The test procedure recommended by Aldomy et al. [10] was followed. Briefly, $30 \mu \mathrm{l}$ of RBPT antigen and $30 \mu \mathrm{l}$ of the test serum were placed alongside on the plate, and then mixed thoroughly. The plate was shaken for $4 \mathrm{~min}$, and the degree of agglutination reactions was recorded. The sample was classified positive if any agglutination was observed and negative if no agglutination were seen. It was observed that out of 14 samples from Group II, 8 samples were positive, and 6 were negative for Brucella. The blood samples positive for Brucella and blood collected from healthy cows were subjected to biochemical analysis. The serum was stored at $-20^{\circ} \mathrm{C}$ for further analysis. The biochemical analytes ie protein, albumin, glucose, cholesterol, triglyceride, urea, blood urea nitrogen(BUN), aspartate transaminase (AST) and alanine transaminase (ALT) were estimated spectrophotometrically by Systronic 20 using commercially available kits [11].

\section{Statistical analysis}

The data were analyzed by paired student $t$-test method described by Snedecor and Cochran [12]. Differences were considered as significant at $\mathrm{p}<0.05$.

\section{Results}

Brucellosis is a zoonotic disease transmitted by direct or indirect contact with infected animals, soiled pasture and corrals, ingesting infected milk and with semen from male to female animals $[13,14]$. In this study, the effects of Brucella infection on cow's health and performances were investigated through examining the changes in the blood metabolites of the infected animals. These parameters give an indication about the effects of these causative agents on animal's health and performance. The blood samples were screened for Brucella and 53.33\% were true positive and $46.67 \%$ were false negative. The mean \pmstandard error of different biochemical parameters of healthy and brucellosis affected cows are summarized in Table-1. It was observed that serum albumin and urea of the affected cattle showed a significant decrease $(p<0.05)$ when compared with the healthy cows. Serum albumin and urea decreased from
Table-1: Mean \pm Standard error of plasma biochemical parameters in healthy and Brucella infected cows.

\begin{tabular}{lcc}
\hline $\begin{array}{l}\text { Biochemical } \\
\text { parameters }\end{array}$ & $\begin{array}{c}\text { Group I } \\
\text { (Healthy } \\
\text { cows; n=6) }\end{array}$ & $\begin{array}{c}\text { Group II (Cows } \\
\text { infected with } \\
\text { Brucella; n=8) }\end{array}$ \\
\hline Total protein (g/dl) & $5.6225 \pm 0.1722^{\mathrm{a}}$ & $5.21 \pm 0.218^{\mathrm{a}}$ \\
Albumin $(\mathrm{g} / \mathrm{dl})$ & $3.1275 \pm 0.131^{\mathrm{a}}$ & $2.1057 \pm 0.276^{\mathrm{b}}$ \\
Globulin (g/dl) & $2.4737 \pm 0.221^{\mathrm{a}}$ & $3.132 \pm 0.277^{\mathrm{b}}$ \\
A: G ratio & $1.3613 \pm 0.157^{\mathrm{a}}$ & $0.8086 \pm 0.221^{\mathrm{a}}$ \\
Glucose (mg/dl) & $50.173 \pm 2.353^{\mathrm{a}}$ & $47.9957 \pm 2.7835^{\mathrm{a}}$ \\
Triglyceride (mg/dl) & $29.643 \pm 2.988^{\mathrm{a}}$ & $36.603 \pm 1.746^{\mathrm{b}}$ \\
Cholesterol (mg/dl) & $86.702 \pm 3.937^{\mathrm{a}}$ & $95.892 \pm 1.740^{\mathrm{b}}$ \\
Urea (mg/dl) & $39.832 \pm 5.788^{\mathrm{a}}$ & $26.600 \pm 3.660^{\mathrm{b}}$ \\
Blood urea & $1.3613 \pm 0.157^{\mathrm{a}}$ & $0.8086 \pm 0.221^{\mathrm{a}}$ \\
nitrogen (mg/dl) & & \\
Aspartate & $69.022 \pm 3.187^{\mathrm{a}}$ & $95.105 \pm 5.582^{\mathrm{b}}$ \\
transaminase (U/L) & & \\
Alanine & $14.789 \pm 2.840^{\mathrm{a}}$ & $19.717 \pm 2.331^{\mathrm{b}}$ \\
transaminase (U/L) & & \\
\hline Mean with diferent & &
\end{tabular}

Mean with different superscripts denotes significance $(p<0.05)$ difference between the rows.

$3.1275 \pm 0.131$ to $2.1057 \pm 0.276 \mathrm{~g} / \mathrm{dl}$, and $39.832 \pm 5.788$ to $26.6 \pm 3.660 \mathrm{mg} / \mathrm{dl}$ respectively. However, serum globulin, cholesterol, triglyceride showed a significant increase $(\mathrm{p}<0.05)$ with that of the healthy cattle. Serum globulin, cholesterol and triglyceride increased from $2.4737 \pm 0.221$ to $3.132 \pm 0.277 \mathrm{~g} / \mathrm{dl}, 86.702 \pm 3.937$ to $95.892 \pm 1.740 \mathrm{mg} / \mathrm{dl}$ and $29.643 \pm 2.988$ to $36.603 \pm 1.746 \mathrm{mg} / \mathrm{dl}$ respectively. Glucose, total protein, A:G ratio and blood urea nitrogen did not show much variation between the brucellosis affected and healthy cattle. The liver enzymes aspartate transaminase (AST) and alanine transaminase (ALT) increased significantly $(\mathrm{p}<0.05)$ from $69.022 \pm 3.187$ to $95.105 \pm 5.582$ and $14.789 \pm 2.840$ to $19.717 \pm 2.331$ $\mathrm{I} / \mathrm{U}$, respectively.

\section{Discussion}

Our results are in compliance with the results of Hamada et al. [15] and Abenga and Anosa [16]. They also observed an increased serum globulin level in Brucella affected cows indicating that the parasite infection increased serum gamma globulins in infected animals that may due to host parasite interaction. Hypertriglyceridemia in cows affected with brucellosis were also reported earlier by Bouhroum et al. [7]. This is explained by the fact that $B$. abortus is a gram negative intracellular bacterium; it induces the production of tumor necrosis factor alpha (TNF- $\alpha)[15,17]$ and the production of TNF- $\alpha$ inhibits the lipoprotein lipase, which results in elevated plasma triglyceride [18]. These findings are in line with Al-Kaysi et al. [19] and Al-Hussary et al. [20] who found that serum levels of albumin were reduced in animals infected with Brucella while the activities of both AST and ALT were increased significantly $(\mathrm{p}<0.05)$; while Gul et al. [21] found a significant $(\mathrm{p}<0.05)$ increase ALT activity and total protein showed no significant difference. El-Boshy et al. [6] also reported a significant $(\mathrm{p}<0.05)$ decrease in total protein, albumin and 
glucose but a significant $(\mathrm{p}<0.05)$ increase ALT and AST activities in camel. Due to liver damage caused by Brucella there was an increase in the release of liver enzymes into the plasma while decreased albumin synthesis by reticuloendothelium cells in the liver. Furthermore, Brucella may infect and damage the kidney, which increase protein excretion in the urine and lead to hypoalbuminemia [20]. This finding may be ascribed to the hepatic damage caused by brucellosis [6]. Also as the liver maybe damaged during brucellosis and so there was decrease synthesis of albumin and urea in the liver and so there was a there was a significant decrease $(p<0.05)$. They may also decrease due to restricted food intake in infected cows [15].

\section{Conclusion}

Thus, it can be concluded that brucellosis leads to serious changes in the blood as it affects some vital organs like liver. The assaying of biochemical parameters in cattle may be helpful in elucidating the etio-pathogenesis of the adverse effects associated with brucellosis in cattle.

\section{Authors' Contributions}

RN and SS planned and designed the study. RN collected the serum samples, performed the biochemical tests and analyzed the data. SD and MD screened the samples for brucellosis. All authors participated in draft and revision of the manuscript. All authors read and approved the final manuscript.

\section{Acknowledgments}

The authors are thankful to the Dean, Faculty Veterinary Science for providing necessary laboratory facilities to carry out the research work smoothly. The source of fund is departmental fund provide by Assam Agricultural university, Assam.

\section{Competing I nterests}

The authors declare that they have no competing interests.

\section{References}

1. Rajashekara, G., Eskra, L., Mathison, A., Petersen, G., Yu, Q., Harms, J. and Splitter, G. (2006) Brucella; functional genomics and host-pathogen interaction. Anim. Health. Res., 7(1-2): 1-11.

2. Maadi, H., Moharamnejad, M. and Haghi, M. (2011) Prevalence of brucellosis in cattle in Urmia, Iran. Pak. Vet. J., 31: 81-82.

3. Akhtar, R., He, Y.O., Larson, C.B., Chaudhary, Z.I. and Ahmad, M.U.D. (2012) Differential stimulatory activities of smooth and rough Brucella abortus lipopolysaccharide in murine macrophages. Pak. Vet. J., 32: 339-344.

4. Behzadi, M.A. and Mogheiseh, A (2011). Epidemiological survey of Brucella canis infection in different breeds of dogs in Fars province. Pak. Vet. J., 32: 234-236.

5. Abubakar, M., Mansoor, M. and Arshed, M.J. (2012)
Bovine brucellosis: Old and new concepts with Pakistan perspective. Pak. Vet. J., 32: 147-155.

6. El-Boshy, M., Abbas, M., El-Khoderyl, H. and Osman, S. (2009) Cytokine response and clinicopathological findings in Brucella infected camels (Camelus dromedarius). Vet. Med., 54(1): 25-32.

7. Bouhroum, N.L, Bensahli, B. and Niar, A. (2012) Evolution of biochemical parameters in post partum cows affected with Brucella, in the wilaya of Relizane. Afr. J. Biotechnol., 11(7): 1818-1822.

8. Radostits, O.M., Gay, C.C., Hinchcliff, K.W. and Constable, P.D. (2007) Veterinary Medicine: A Textbook of the Diseases of Cattle, Horse, Sheep, Pigs \& Goat. Saunders, St Louis. p1518-1522.

9. Al-Majali, A.M. (2005) Seroepidemiology of caprine Brucellosis in Jordan. Small Rumin. Res., 58: 13-18.

10. Aldomy, F., Alkhawaldeh, M. and Younis, I.B. (2009) Immune responses of goats (Shami breed) to vaccination with a full, reduced and conjunctival dose of brucevac (Brucella melitensis Rev.1) vaccine. Pak. Vet. J., 29: $149-153$.

11. Nath, R (2008) Changes in serum enzymes during experimental aflatoxicosis in broiler chicken. Indian. Vet. J., 85(1): 10-12.

12. Snedecor, G.M., and Cochran, W.G. (1994). Statistical Method. $7^{\text {th }}$ ed. Oxford and IBH Publishing Co, New Delhi.

13. Renukaradhya, G.J., Isloor, S. and Rajasekhar, M. (2002). Epidemiology, zoonotic aspects, vaccination and control/ eradication of brusellosis in India. Vet. Microbiol., 90(1-4): 183-195.

14. Abenga, J.N. and Anosa, V.O. (2005) Serum total protein \& creatine levels in experimental Gambian trypanosomosis of Vervet monkeys. Afr. J. Biotechnol., 4: 187-190.

15. Hamada, D.M., Mohamed, A.H, Mabrouk, A., Emad, M. and Ah, M.E. (2013) Seroprevalence of abortion causing agents in Egyptian sheep and goat breeds and their effects on the animal's performance. J. Agric. Sci., 5(9): 92-101.

16. Bruce, W.J., Tajie, H.H., Nilofer, Q. and Gary, A. (2002). Splitter rough lipopolysaccharide from Brucella abortus and escherichia coli. differentially activates the same mitogen-activated protein kinase signaling pathways for tumor necrosis factor alpha in raw 264.7 macrophage-like cells. Infect. Immun., 70(12): 7165-7168.

17. Huang, L.Y., Alibert, J., Leifer, C.A., Segal, D.M., Sher, A., Golenbock, D.T. and Golding, B. (2003) Heat-killed Brucella abortus induces TNF and IL12p40 by distinct My D88-dependent patways: TNF, unlike IL-12p40 secretion, is Toll-like receptor 2 dependent. J. Immunol., 171(3): 1441-1446.

18. Feingold, K.R., Soued, M., Staprand, I., Gavin, L.A., Donahue, M.E., Huang, B.J., Moser, A.H., Gulli, R. and Grumfeld, C. (1989) Effect of TNF on lipid metabolism in the diabetic rat evidence that inhibition of adipose tissue lipoprotein lipase activity is not required for TNF induced hyperlipidemia. J. Clin. Invest., 83(4): 1116-1121.

19. Al-Kaysi, A.M., Eid, R.A.A., and Fahmy, B.G.A. (2010) Biochemical studies on the effect of Toxoplasma infection on liver and kidney functions in mice. Egypt. J. Comp. Path. Clin. Pathol., 23: 174-185.

20. Al-Hussary, N.A.J. and Al-Zuhairy, A.S.M. (2010) Effect of toxoplasmosis ans brucellosis on some biochemical parameters in ewes. Iraqi. J. Vet. Sci. 24: 73-80.

21. Gul, S.T., Khan, A., Ahmad, M. and Hussain, I. (2013) Seroprevalence of brucellosis and associated hemato-biochemical changes in Pakistani horses. Pak. J. Agric. Sci., 50(4): 745-750. 